\title{
On Black Female Consciousness in the Color Purple
}

\author{
Xia Zhang, Yangjing Ye \\ School of Foreign Languages of Mianyang Normal University, China
}

Keywords: The color purple; Celie; double oppression.

\begin{abstract}
Alice Walker is an Afro-American novelist, poet and activist. The Color Purple is generally acknowledged as her most successful masterpiece, for which she won the National Book Award and the Pulitzer Prize for Fiction. The story focuses on the life of African-American women in the Southern United States in the 1930s. The heroine Celie who lives in the south, after undergoing double oppression of racism and sexism, finally becomes a physically and mentally independent woman. This paper discusses the process of the awakening of the heroine's black female consciousness in The Color Purple under the racial and gender oppression. On the one hand, through the constant pursuit of self-knowledge, Celie finally finds her new position as a woman, and succeeds in seeking a balance relationship between man and woman in a patriarchal society with the help of sisterhood. On the other hand, with the independence of economy and self-awareness, Celie finds her own way in a race-discriminated society as a black woman. Furthermore, the awakening of black female consciousness on these two aspects ultimately makes the sublimation of the character.
\end{abstract}

\section{Introduction}

Alice Walker is an versatile and eminent Afro-American female writer. In 1982, she published The Color Purple, which made her the first Afro-American female writer who won the Pulitzer Prize for fiction. Walker not only focuses on racial discrimination in her writing, but also keeps a watchful eye on the black woman under the sex discrimination, which makes Walker distinct from all other authors of her day and it is for this reason that she coined the term 'womanism'. Her vivid descriptions of black woman in a sexist and racist society are much influenced by her life experiences. Alice Walker was born in a small rural town of Georgia. She witnessed how her parents suffered in a sharecropper's society. The conspicuous racial oppression and poverty confirmed her belief to strive for improving the poor social conditions of Afro-American women through her novels. What's more, Civil Rights Movement and Women's Liberation Movement laid a solid foundation for her struggle.

The Color Purple is Alice Walker's best-known work. It depicts a poor black girl Celie, being abusive and submissive, struggles to find her own worth. In this novel, the protagonist Celie suffers racial and sexism discrimination. At the beginning, Celie is numb under the constant abuses from her stepfather and husband. With the help of the black sisterhood, Celie begins to try to find herself and finally gains the physically and mentally independence. The central theme of the story lies in the awakening and development of black female consciousness. It represents black woman's new definition of femininity, gender equality and social esteem.

\section{Brief analysis of double oppression}

\subsection{The oppression of racism}

Racial discrimination has always been here for a long time. Although slavery has been abolished at last, colored people still have to fight with all kinds of unfairness and discrimination. It often takes the form of social movements, practices or beliefs, or political systems that consider black people to be ranked as inferior to each other. It is so hard for people to eliminate it. In this novel, racism is particularly obvious.

The whole story spans from thirty to forty years in the early nineteenth century which makes the 
ceaseless fight for racism apparent. Sofia Celie's stepdaughter-in-law, refuses to be mayor's wife's maid because his wife is white which causes she is beaten by mayor and other six policemen. When Celie sees Sofia after the beating, she doesn't know why Sofia is still alive. She is swollen from head to foot and just about the color of an eggplant. Once mayor's wife allows Sofia to see her children and it has been five years since she left home being mayor's wife's maid. However, because mayor's wife doesn't know how to operate the gear that ends up with Sofia only has fifteen minutes with her children. As a matter of fact, Sofia is a robust and emulative woman, but she becomes obedient after brutal beating. Sofia is completely changed because ultimately she knows that she doesn't have the rights to fight in a white-dominated society. Celie is also a typical victim, who once had a happy family. From the very beginning, Celie's own father was a well-to-do farmer who owned his own property and he ran a store selling dry goods. Then the white merchants began to complain the store was taking all the black business away from them. Therefore, one night, Celie's own father's store was burned down, and he and his two brothers were dragged out of their homes in the middle of night and hanged by the white merchants.

If Celie's own father was not lynched by the white men, or the racial discrimination was not rampant at that time, Celie's mother wouldn't go crazy and marry to a tyrannical man who beats and abuses Celie a lot. If all these things haven't happened, Celie would be in a happy family and would never be maltreated by her stepfather. Celie would be a girl with self-cognition and live a life of her own if black people were not considered to be inferior to the white.

What deserves to be mentioned more is that all the black people are under the prejudice and discrimination of white people, no matter men or women, so in this case men are more inclined to give vent to their unjust treatment from the white to the poor black women. It is an important reason that leads black women gradually lose their self-cognition. However, the fight for equal position of black and white goes on all the time, black women have been enduring double oppression which make them no dignity and no value.

\subsection{The oppression of sexism}

In the patriarchal society, men dominate everything. They hold the power of defining and naming, which helps them to strengthen their dominance and superiority. In The Color Purple, sex discrimination is one of the themes in the whole novel, while this theme is not frequently involved in other African-American writers' novel atn that time, which makes the book quite distinctive. The protagonist Celie is a poor girl. Because of her mother's illness, her stepfather asks her to do what her mother couldn't do. She is often bullied and sexual assaulted by her stepfather, which makes her gives birth to two kids when she is a teenager. She becomes her stepfather's sexual tool and she has to babysit her brothers and sisters. Her own mother never care for her instead of cussing and screaming at her. After her mother died, her stepfather can't stand her anymore and forces her to marry Mr. —, just like trading her as goods. her life was much worse. On the wedding day, she got injured because her stepson Harpo threw rocks at her. She was treated as a working machine and had to meet Mr._'s sexual desire, let alone fiercely beating. The two men, her stepfather and husband became her nightmare. She couldn't feel anything just as numb as a tree.

Black women's position is especially low in a men-dominated society and this phenomenon has a deep influence on the offspring. Harpo wants to subjugate his wife Sofia in his father's way. He carries on the same desire of his father--to make women under men's control. Celie, facing all these unfair treatments from men, began to lose the faith in life and accept the idea that men dominate everything. She envied Sofia's insubordination, and also advised Harpo to beat Sofia. It is as if all black women are under the bottom of society. They suffer not only maltreats in a patriarchal society, but also racial discrimination of white people. All of these sufferings deprive black women's consciousness and it is a long way to realize real equality. 


\section{The awakening of black female consciousness}

\subsection{The improvement of relationship between men and women}

For a long time, black women have been suffered a lot of assaults physically and mentally in the patriarchal society. Black men always lose their bad temper on women. And black women are considered as lower in social position. However, in the Color Purple, the author molds a different image of the heroine. The main figure Celie shows a black woman's self-cognition and value. Celie was submissive and obedient undergoing constant abuses from her stepfather and husband at the beginning of the story. Then with the influence of Shug, Celie began to search for self-positioning as a woman instead of a tree. She starts to appreciate herself as a woman and gradually breaks the permanent silence of being blindly obedient. In the end, she manages to find a position equal to black man and finally keeps a harmonious relationship with black men

\subsection{The development of black women's social status}

When we talk about about the development of black women's social status, we pay more attention to the black women's reversal of status in the white-dominated world. Since the first day when Afro-Americans were shipped as the slaves to the United, they were compelled to discard their own language and culture, and they were completely subordinated to the white people. Although the slavery has been abolished for a long time, the black people still lives in bad living conditions due to the racial discrimination. The black women, as we know, can be regarded as the most special group in the society, because not only are they black, but female. In the last chapter, we have discussed that the black female character Celie has already got the physically independence, so here we will analyze how she gets respect from the society and improves her social status.

Economic independence is the important basic guarantee of social independence for Celie. When Walker explains why black women characters are poor in The Color Purple, she says that one is women's incapacity in financing, and the other is the patriarchal system. Virginia Woolf once stresses in her prose that a woman needs enough money and a room to guarantee her independence in the society. This is also the reason why Shug could live life her own way, while Celie couldn't. Only if women gain the economically and spiritually independence can they get rid of the inferior social position. At first, Celie's economical inadequacy is astonishing, but fortunately, she finds out the way. Sewing is a kind of common handcrafts to women. In order to make a living, Celie begins to make pants for people. Celie presents her own personality in designing pants of different styles which fit people well. By making pants, Celie finds back her confidence because she receives good praise by other people. Because of these praise, Celie assures her self-value as a woman in the society. Meanwhile, wearing pants is a way for black women to show their identity. In the past, it's men's privilege to wear pants, but now Celie and other black women put on the pants freely. They are not submissive anymore, instead of being full of rebellious spirit. What's more, due to the expansion of the pants-making company, Celie hires lots of people to run the company, including white people. It shows it is because of economic independence that brings Celie the same position as white people. Besides having her own earning, Celie also manages to have a house of her own which guarantees her final independence in the society. She paints her house purple and red which are the colors she once wants to wear on her body. When the story comes to end, Celie obtains economic achievements and she is respected from the others. So far Celie's consciousness for economic independence has awakened, which contribute to her improved status in the society.

\section{Conclusion}

In fact, Alice Walker is a womanist. She argues that a womanist should strive for the survival and wholeness of entire human race. Through the civil rights movement, Walker realizes that racial discrimination is not only the yoke upon black men but also the cause of black women's suffering. While the feminist movement lets her realize that the plight of black women is distinct expect for the 
universality of female problems. And the oppression of black women is far more than white women and black men, because they have to face the double oppression of racism and sexism.

In The Color purple, Alice Walker emphasizes the double oppression that black women have to endure in the American community. She depicts the images of strong and independent black women to run counter the dilemma of double oppression from a female point of view. The protagonist Celie, from numbness and inferiority to an independent and successful woman who achieves the awakening of black women's consciousness, including three aspects of self-cognition as a woman, consciousness of gender equality and social esteem. And Celie's every awareness is always accompanied with encouragement or help of other women. That is to say, sisterhood is the most important power that helps Celie to fight against the injustice in the society. In the man-dominated society, women are ignored physically and psychologically. Therefore, only through sisterhood can women get some concern and help.

The Color Purple is a successful representation of Alice Walker's womanism. The primary theme of The Color Purple reflects Walker's womanist idea of creating a positive outcome in life under the harsh conditions, which sets a good example for women who are undergoing oppression that if you tend to pursue the goal to be survival, you should take the responsibility for yourself and struggle to grow up into a whole being with self-awareness.

\section{References}

[1] Williams, Chris. A Close Reading into The Color Purple. New York: Penguin,2007.

[2] Kenyon, Olga. Writing Women: Contemporary Women Novelist[Z]

[3] Bell Hooks, Feminist Theory: From Margin to Center, Boston: South End Press, 1989.

[4] Code, Lorraine, ed. Encyclopedia of Feminist Theories. New York: Routeledge, 2000

[5] Zora Neale Hurston, Their Eyes Were Watching God, New York: Harper Perennial, 1989 